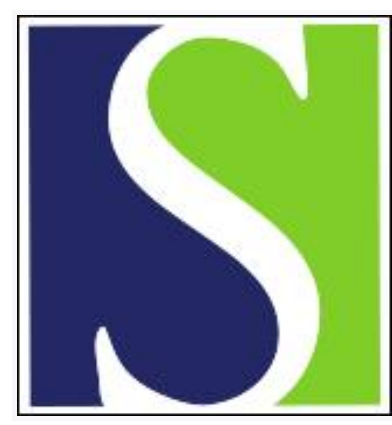

Scand J Work Environ Health 2006;32(3):171-177

https://doi.org/10.5271/sjweh.995

Issue date: 30 Jun 2006

Meta-analysis of mobile phone use and intracranial tumors

by Lahkola A, Tokola K, Auvinen A

Affiliation: STUK-Radiation and Nuclear Safety Authority, PO Box 14, FI-00881 Helsinki, Finland. anna.lahkola@stuk.fi

The following articles refer to this text: 2006;32(3):169-170;

2010;36(6):515-516

Key terms: brain neoplasm; cellular phone; intracranial tumor; meta-analysis; mobile phone use; pooled analysis

This article in PubMed: www.ncbi.nlm.nih.gov/pubmed/16804618 


\title{
Meta-analysis of mobile phone use and intracranial tumors
}

\author{
by Anna Lahkola, MSc, ${ }^{1}$ Kari Tokola, MSc, ${ }^{1}$ Anssi Auvinen, PhD ${ }^{1,2}$
}

\begin{abstract}
Lahkola A, Tokola K, Auvinen A. Meta-analysis of mobile phone use and intracranial tumors. Scand J Work
\end{abstract} Environ Health 2006;32(3):171-177.

\begin{abstract}
Objectives A summary of epidemiologic evidence regarding the effect of mobile phone use on intracranial tumor risk was obtained by means of a meta-analysis.

Methods Reports of published studies on mobile phone use and intracranial tumors were sought. Altogether 12 relevant publications were identified from the PubMed database and reference lists of articles. Fixed or random effects analysis was carried out depending on the presence of heterogeneity between studies. Risk estimates were obtained for people who had used mobile phones for the longest periods of time ( $>5$ years in most reports). A pooled estimate was calculated for all intracranial tumors combined and also separately for different histological tumor types. Separate analyses were conducted also based on the tumor location and type of mobile telephone network (NMT or GSM).

Results Twelve studies with 2780 cases gave a pooled odds ratio (OR) of 0.98 [95\% confidence interval (95\% CI) $0.83-1.16$ ] for all intracranial tumors related to mobile phone use. For gliomas, the pooled OR was 0.96 (95\% CI 0.78-1.18), for meningiomas it was 0.87 (95\% CI 0.72-1.05), and for acoustic neuromas it was 1.07 (95\% CI 0.89-1.30). Little indication was found for increased risks of analogue or digital phone use or temporal or occipital tumors.

Conclusions The totality of evidence does not indicate a substantially increased risk of intracranial tumors from mobile phone use for a period of at least 5 years.
\end{abstract}

Key terms brain neoplasm; cellular phone; pooled analysis.

The use of mobile phones (also called cellular phones) has increased rapidly worldwide since the early 1990s. This increase has generated concern about the possible adverse health effects of mobile phone use, particularly the risk of intracranial tumors.

The first study concerning the association between intracranial tumors and mobile phone use was published in 1999 (1). After this case-control study, which did not report any significantly increased risks of intracranial tumors among mobile phone users, several studies have appeared in the literature. However, the published results are somewhat inconsistent, and single studies appear inconclusive. Several reviews summarizing the results have been published and most conclude that mobile phones are not likely to cause intracranial tumors (2-6). To complement the qualitative summaries provided by the reviews, a meta-analysis provides a tool for the quantitative synthesis of individual studies. A meta-analysis was used to estimate the overall magnitude of the risk for intracranial tumors, comprised of brain tumors such as gliomas and meningiomas, as well as acoustic neuromas, in relation to mobile phone use.

\section{Material and methods}

We searched for the epidemiologic evidence on mobile phone use and intracranial tumors in the PubMed database (www.ncbi.nlm.nih.gov) using the following searching terms (used in the title or abstract): (1) mobile/cellular phone/telephone and (2) brain tumor/cancer/neoplasm or glioma or meningioma or neuroma/ schwannoma. In addition, we browsed the reference lists of the retrieved articles. We obtained a numerical summary of the published results without a detailed qualitative review of individual studies. Such reviews have been published previously (2-6).

Altogether 19 articles $(1,7-24)$, published by 1 December 2005 , were identified that meet the following

1 Säteilyturvakeskus (STUK, Radiation and Nuclear Safety Authority), Helsinki, Finland.

2 Tampere School of Public Health, University of Tampere, Tampere, Finland.

Reprint requests to: Anna Lahkola, STUK-Radiation and Nuclear Safety Authority, PO Box 14, FI-00881 Helsinki, Finland. [E-mail: anna.lahkola@stuk.fi] 
inclusion criteria: (i) being original publications, (ii) using individual exposure data, (iii) based on a casecontrol or cohort format, (iv) reporting quantitative measures of association [point estimates expressed either as odds ratios (OR) or as standardized incidence ratios (SIR)], and (v) reporting information needed for the estimation of confidence intervals (the standard error or confidence interval of the effect measure or the number of persons by exposure and outcome status). A meta-analysis requires that the studies to be pooled have similar aims and end points. One study was excluded because the end point was brain tumor mortality rather than incidence, and another was excluded that addressed only facial nerve tumors (7-8). No studies were excluded due to language other than English, and no unpublished reports were identified. No studies were excluded because of dissimilar procedures, as both the inclusion criteria and exposure assessment methods were similar enough to allow pooling. As the approaches were relatively uniform, no grading by quality was regarded as necessary.

We were able to retrieve all of the 17 identified studies fulfilling the criteria. On the basis of the considerations, five articles $(9-11,18-19)$ were excluded from the analysis because they used overlapping study participants of other articles that were already included in the material. Altogether 12 studies (1, 12-17, 20-24) were finally included in the analysis (table 1). Of these studies, nine were population-based (1, 14-16, 20-24), and three were hospital-based $(12-13,17)$. All of the hospital-based studies were carried out in the United States, while the population-based studies were European. Eleven were case-control studies $(1,12-13,15-$ 17, 20-24), and one was a cohort study (14). All of the studies included in the meta-analysis used incident intracranial tumor cases. Exposure assessment was based on interviews or questionnaires in all but two studies that used telephone company records (14-15). Six of the

Table 1. Key features of the studies included in the meta-analysis. (OR $=$ odds ratio, $95 \% \mathrm{Cl}=95 \%$ confidence interval, US = United States)

\begin{tabular}{|c|c|c|c|c|c|c|c|c|}
\hline Study & Country & End points & Number ${ }^{\mathrm{a}}$ & Exposure assessment & $\begin{array}{l}\text { Telephone } \\
\text { types }\end{array}$ & $\begin{array}{l}\text { Longest } \\
\text { duration } \\
\text { of mobile } \\
\text { phone use }\end{array}$ & $O R^{b}$ & $95 \% \mathrm{Cl}^{\mathrm{b}}$ \\
\hline $\begin{array}{l}\text { Hardell et al, } \\
1999 \text { (1) }\end{array}$ & Sweden & $\begin{array}{l}\text { Intracranial tumors (astrocytic, oligo } \\
\text { dendroglial and ependymal tumors, } \\
\text { mixed glioma, meningioma) }\end{array}$ & $\begin{array}{l}34 \text { cases, } \\
69 \text { controls }\end{array}$ & $\begin{array}{l}\text { Postal questionnaire }+ \\
\text { telephone interview }\end{array}$ & $\begin{array}{l}\text { Analogue, } \\
\text { digital }\end{array}$ & $>5$ years & 0.83 & $0.49-1.42$ \\
\hline $\begin{array}{l}\text { Muscat et al, } \\
2000(12)\end{array}$ & US & $\begin{array}{l}\text { Malign intracranial tumors (astrocytic, } \\
\text { oligodendroglial and ependymal } \\
\text { tumors, mixed glioma) }\end{array}$ & $\begin{array}{l}17 \text { cases, } \\
22 \text { controls }\end{array}$ & Interview & $\begin{array}{l}\text { Not } \\
\text { specified }\end{array}$ & $>4$ years & 0.7 & $0.4-1.4$ \\
\hline $\begin{array}{l}\text { Inskip et al, } \\
2001 \text { (13) }\end{array}$ & US & $\begin{array}{l}\text { Intracranial tumors (glioma, menin- } \\
\text { gioma, acoustic neuroma) }\end{array}$ & $\begin{array}{l}22 \text { cases, } \\
31 \text { controls }\end{array}$ & Interview & $\begin{array}{l}\text { Not } \\
\text { specified }\end{array}$ & $>5$ years & $0.9^{c}$ & $0.5-1.6$ \\
\hline $\begin{array}{l}\text { Johansen et al, } \\
2001 \text { (14) }\end{array}$ & Denmark & $\begin{array}{l}\text { Cancer (brain and nervous system, } \\
\text { gliomas, meningiomas) }\end{array}$ & $\begin{array}{l}66 \text { gliomas, } \\
16 \text { menin- }^{-} \\
\text {giomas }^{d}\end{array}$ & $\begin{array}{l}\text { Company records, } \\
420095 \text { mobile phone } \\
\text { subscribers }\end{array}$ & $\begin{array}{l}\text { Not } \\
\text { specified }\end{array}$ & $\begin{array}{l}\text { Mean } \\
\text { follow-up } \\
\text { time } \\
3.1 \text { years }\end{array}$ & $0.92^{e, f}$ & $0.74-1.16$ \\
\hline $\begin{array}{l}\text { Auvinen et al, } \\
2002 \text { (15) }\end{array}$ & Finland & $\begin{array}{l}\text { Intracranial tumors (glioma, } \\
\text { meningioma) }\end{array}$ & $\begin{array}{l}18 \text { cases, } \\
64 \text { controls }\end{array}$ & Company records & $\begin{array}{l}\text { Analogue, } \\
\text { digital }\end{array}$ & $>2$ years & 1.5 & $0.9-2.5$ \\
\hline $\begin{array}{l}\text { Hardell et al, } \\
2002(16)\end{array}$ & Sweden & $\begin{array}{l}\text { Intracranial tumors (astrocytic, oligo- } \\
\text { dendroglial and ependymal tumors, } \\
\text { mixed glioma, meningioma, pituitary } \\
\text { tumors, acoustic neuroma) }\end{array}$ & $\begin{array}{l}153 \text { cases, } \\
124 \text { controls }\end{array}$ & $\begin{array}{l}\text { Postal questionnaire + } \\
\text { telephone interview }\end{array}$ & $\begin{array}{l}\text { Analogue, } \\
\text { digital }\end{array}$ & $>5$ years & $0.9^{9}$ & $0.6-1.5$ \\
\hline $\begin{array}{l}\text { Muscat et al, } \\
2002(17)\end{array}$ & US & Acoustic neuroma & $\begin{array}{l}11 \text { cases, } \\
6 \text { controls }\end{array}$ & Interview & $\begin{array}{l}\text { Not } \\
\text { specified }\end{array}$ & $3-6$ years & 1.7 & $0.5-5.1$ \\
\hline $\begin{array}{l}\text { Lönn et al, } \\
2005 \text { (20) }\end{array}$ & Sweden & Glioma, meningioma & $\begin{array}{l}136 \text { cases, } \\
171 \text { controls }\end{array}$ & Interview & $\begin{array}{l}\text { Analogue, } \\
\text { digital }\end{array}$ & $>5$ years $^{h}$ & $0.73^{\dagger}$ & $0.55-0.96$ \\
\hline $\begin{array}{l}\text { Christensen et } \\
\text { al, } 2005(21)\end{array}$ & Denmark & Glioma, meningioma & $\begin{array}{l}83 \text { cases, } \\
193 \text { controls }\end{array}$ & Interview & $\begin{array}{l}\text { Not } \\
\text { specified }\end{array}$ & $>5$ years $^{h}$ & $0.66^{\dagger}$ & $0.46-0.95$ \\
\hline $\begin{array}{l}\text { Schoemaker et } \\
\text { al, } 2005 \text { (22) }\end{array}$ & $\begin{array}{l}\text { Nordic } \\
\text { countries }\end{array}$ & Acoustic neuroma & $\begin{array}{l}127 \text { cases, } \\
646 \text { controls }\end{array}$ & Interview & $\begin{array}{l}\text { Analogue, } \\
\text { digital }\end{array}$ & $>5$ years $^{h}$ & $0.95^{f}$ & $0.75-1.18$ \\
\hline $\begin{array}{l}\text { Hardell et al, } \\
2005 \text { (23) }\end{array}$ & Sweden & Acoustic neuroma, meningioma & $\begin{array}{l}87 \text { cases, } \\
129 \text { controls }\end{array}$ & $\begin{array}{l}\text { Postal questionnaire + } \\
\text { telephone interview }\end{array}$ & $\begin{array}{l}\text { Analogue, } \\
\text { digital }\end{array}$ & $>5$ years $^{\mathrm{h}}$ & $1.4^{f}$ & $1.02-1.93$ \\
\hline $\begin{array}{l}\text { Hardell et al, } \\
\text { (in press) (24) }\end{array}$ & Sweden & Malign intracranial tumors & $\begin{array}{l}98 \text { cases, } \\
129 \text { controls }\end{array}$ & $\begin{array}{l}\text { Postal questionnaire + } \\
\text { telephone interview }\end{array}$ & $\begin{array}{l}\text { Analogue, } \\
\text { digital }\end{array}$ & $>5$ years ${ }^{h}$ & $1.49^{\dagger}$ & $1.10-2.02$ \\
\hline
\end{tabular}

${ }^{a}$ The number of cases and controls in the subcategories of the original studies that are included in the meta-analysis. The subcategories were selected to achieve the maximum length of mobile phone use.

${ }^{\mathrm{b}}$ The overall estimate for the use of mobile phones that was used in the meta-analysis.

${ }^{c}$ Relative risk.

${ }^{d}$ Among mobile phone users (a cohort study with 135 cancer cases of the brain and nervous system).

e Standardized incidence ratio.

${ }^{\dagger}$ Calculated by the authors of the meta-analysis through the pooling of different exposure or tumor categories reported in the original studies.

9 Digital phones.

${ }^{\mathrm{h}}$ Calculated by pooling the original categories in the articles, $5-9$ years (or $5-10$ ) and $>10$ years, to one category of $>5$ years. 
studies $(1,16,20,22,23-24)$ reported excluding the exposure within $\leq 1$ year from the index date (diagnosis of cases and corresponding date among the controls) in the analysis, while such restriction of exposure was not reported in the rest of the studies. The participation rates among the cases varied between $73 \%$ and $92 \%$, and among controls it ranged from $51 \%$ and $91 \%$.

The articles to be included in the analyses were reviewed independently by two authors (AL \& KT), and all of the relevant data (odds ratios, relative risks, and standardized incidence ratios with $95 \%$ confidence intervals) were retrieved and entered into evidence tables.

In the absence of heterogeneity, we carried out the meta-analysis using the inverse variance-weighted method for combining the odds ratios (25). This approach is equivalent to a fixed-effects analysis, on the assumption that the effect is constant across studies and all differences between the studies are attributable to random variation (25). Most of the studies used identical factors, such as age and gender, for matching or adjustment. The weights were calculated on the basis of the width (subtraction of the lower and upper limit) of the confidence interval (CI), due to problems with the rounding of the original confidence intervals in some of the studies. When evidence for heterogeneity between studies was found, a random effects analysis was used, which allowed the true risks to vary between studies and assumed a random distribution for these estimates around a common central value.

To improve the accuracy, we recalculated the overall odds ratio for intracranial tumors for one study (16) because the original confidence intervals in the article were reported only with one decimal. For four studies (20, 22-24), we pooled two exposure categories, 5-9 years (or 5-10 years) and $>10$ years into $>5$ years, to achieve similar exposure classification as in the other reports. Furthermore, different tumor categories were also pooled prior to the meta-analysis of the total odds ratio (all tumors combined) for the articles that reported them only separately $(14,21)$. When the estimates were reported only separately for analogue and digital phones (but not for all mobile phones combined), we used the odds ratio for digital phones for the calculations of the total odds ratio since it is possible that the same persons had been using both analogue and digital telephones and thus were included in both categories in the original reports $(16,23-24)$. In addition, digital phone use was more common in most studies.

Our analysis concentrated on the persons most likely to demonstrate an effect, if such exists (ie, the exposed group was defined as those who had used a mobile phone for the longest time, rather than ever users). In most studies, these persons were those with at least 5 years of use, but, in four studies, the longest period was shorter (4 years, from 3 to 6 years, 2 years and the cohort study with the mean follow-up time of 3.1 years, table 1). A pooled odds ratio was calculated for all intracranial tumors combined, based on both duration (years) and cumulative hours of mobile phone use. The odds ratio was also calculated separately for the following three histological groups of tumors: gliomas (comprising astrocytic, oligodendroglial, and ependymal tumors, as well as mixed gliomas-nine studies), meningiomas (eight studies), and acoustic neuromas (six studies). Furthermore, a pooled estimate was calculated separately for telephone types (analogue and digital, seven studies), laterality (reported phone use on the same and opposite side of the head where the tumor occurred, seven and five studies, respectively), study base (hospitalbased versus population-based, 12 studies), as well as tumors of the temporal (excluding acoustic neuromas, eight studies), and occipital lobes (five studies). Finally, we also conducted analyses of ipsilaterality (phone use on the same side that the tumor occurred) by tumor type.

Study heterogeneity was assessed using the Q statistic to determine whether the results of various studies were consistent enough to be combined. Furthermore, we assessed sensitivity (influence of single studies) by calculating pooled estimates while excluding each study at a time. The effect of possible publication bias was investigated by means of a funnel plot. Finally, we performed a regression analysis to assess whether the intracranial tumor risk was related to the duration of mobile phone use. The regression analysis was based on all but the one study that used a cohort design (14). In the analysis, we used the geometric mean of the duration of mobile phone use and weighted odds ratios from each study as in the meta-analysis. From the studies, we included the maximum number of exposure categories available in the published reports. For each exposure category, the duration of use was assigned as the geometric mean of the lower and upper limit of that category. If the authors had not reported an upper limit for the duration of mobile phone use, we estimated the maximal duration by assuming that the use of mobile phones had started in 1987 when the first handheld mobile telephones were introduced. The regression analysis was carried out only for all tumor types combined.

\section{Results}

The total number of cases in the published studies was 5799, of which 2424 were among mobile phone users. Our analyses included a total of 2870 cases, including 748 cases with at least $2-5$ years of mobile phone use. The largest subgroup was gliomas (total 1352 cases, 339 classified as exposed in this analysis), followed by 
meningiomas (527 and 149), and acoustic neuromas (605 and 167). These figures have some uncertainties since the number of persons in different exposure or tumor categories were not reported in some reports $(1,16$, 23-24). The proportion of microscopically confirmed cases ranged between $25 \%$ and $100 \%$ (the lower percentage is related to acoustic neuromas that are usually detected in computer scans).

As there was evidence for heterogeneity between the studies for all tumor types combined on the basis of the duration of mobile phone use, a random effects model was used. The pooled estimate based on the 11 studies was very close to unity, and the upper limit of the confidence interval was below 1.2 (figure 1). The sensitivity analysis showed that the odds ratio was not strongly influenced by any single study (figure 2).

The pooled odds ratio for all tumors combined, on the basis of the cumulative hours of mobile phone use,



Figure 1. Results of the original studies and meta-analysis (random effects model) of mobile phone use and intracranial tumors. The odds ratios are on a $\log$ scale. Pooled odds ratio $=0.98(95 \%$ confidence interval $0.83-1.16$ ). It is indicated which studies included gliomas, ${ }^{1}$ meningiomas, ${ }^{2}$ and acoustic neuromas. ${ }^{3}$

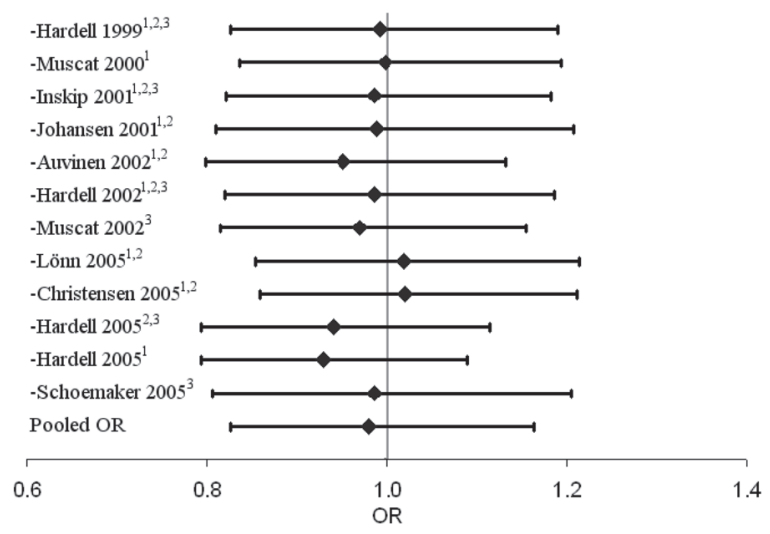

Figure 2. Results of the sensitivity analysis for all types of intracrania tumors combined based on the duration of mobile phone use (years). Each study was excluded at a time from the analysis to assess its influence. The study removed from the analysis is indicated next to the error bar. It is indicated which studies included gliomas, ${ }^{1}$ meningiomas, ${ }^{2}$ and acoustic neuromas. ${ }^{3}$ was very close to unity and was obtained from a random effects model (table 2). The type of study base had little influence on the results, as the pooled odds ratio for the population-based studies (from the random effects model) was only slightly higher than that of the hospital-based studies, obtained from the fixed effects model (table 2).

The analyses by histological type gave similar results. The pooled odds ratios for gliomas (from the random effects model) and meningiomas (from the fixed effects model) were slightly below one, whereas, for acoustic neuromas (from the fixed effects model), the estimate was slightly above one (table 2). The exclusion of the four studies with a maximal exposure duration shorter than 5 years did not materially affect the results for any tumor type.

The pooled estimates for the use of analogue and digital telephones were obtained with a random effects analysis and were both slightly above one and nonsignificant. The pooled odds ratio for analogue telephones was somewhat higher than for digital telephones. No evidence of increased risks was found for temporal or occipital tumors, on the basis of the random and fixed effects model, respectively. However, for the ipsilateral tumors (ie, those occurring on the same side on which the phone was predominantly used) the odds ratio was above one, with borderline nonsignificance. When the tumor types were analyzed separately by laterality in relation to phone use, a nonsignificantly elevated odds ratio was found for the ipsilateral gliomas, whereas the odds ratios were closer to unity for meningiomas and acoustic neuromas. The odds ratio for the contralateral tumors was very close to one (table 2).

In the regression analysis, we found little evidence of an increasing risk of intracranial tumors with duration of mobile phone use (regression coefficient 0.0072 , $\mathrm{P}=0.41$ ). Finally, a funnel plot was used to assess possible publication bias, but it revealed no indication of such selection (figure 3 ).

\section{Discussion}

Our objective was to pool published risk estimates and thereby assess the influence of random variation and heterogeneity between the study results. This meta-analysis showed little evidence of an association between mobile phone use and the risk of all intracranial tumors combined. Our findings are in line with the previously narrative summaries in which the quality of the studies also included in this meta-analysis has been assessed (5, 26). In the subgroup analyses, no strong or consistent association was found with different subgroups of tumors defined by morphologic type (glioma, meningioma, 
Table 2. Pooled estimates of intracranial tumor risk among mobile phone users and measures of heterogeneity between the studies included in the analyses.

\begin{tabular}{|c|c|c|c|c|c|c|}
\hline \multirow{2}{*}{$\begin{array}{l}\text { Tumor type(s), } \\
\text { or other } \\
\text { restrictions }\end{array}$} & \multirow[t]{2}{*}{ Included studies } & \multirow[t]{2}{*}{ Model } & \multirow{2}{*}{$\begin{array}{l}\text { Pooled } \\
\text { OR }\end{array}$} & \multirow{2}{*}{$95 \% \mathrm{Cl}$} & \multicolumn{2}{|c|}{ Heterogeneity } \\
\hline & & & & & $\begin{array}{l}\text { Fixed effect } \\
\text { analysis }\end{array}$ & $\begin{array}{l}\text { Random } \\
\text { effect analysis }\end{array}$ \\
\hline $\begin{array}{l}\text { All intracranial } \\
\text { tumors, duration } \\
\text { of mobile phone }^{\text {use (years) }}{ }^{\text {a }}\end{array}$ & $\begin{array}{l}\text { Hardell et al } 1999 \text { (1), Muscat et al } 2000 \text { (12), Inskip et al } \\
2001 \text { (13), Johansen et al } 2001 \text { (14), Auvinen et al } 2002 \text { (15), } \\
\text { Hardell et al } 2002 \text { (16), Muscat et al } 2002 \text { (17), Lönn et al } \\
2005 \text { (20), Christensen et al } 2005 \text { (21), Schoemaker et al } \\
2005 \text { (22), Hardell et al } 2005 \text { (23), Hardell et al } 2005 \text { (24) }\end{array}$ & Random effects & 0.98 & $0.83-1.16$ & $\begin{array}{l}\chi^{2}=26.67 \\
P=0.01\end{array}$ & $\begin{array}{l}\chi^{2}=10.88 \\
P=0.45\end{array}$ \\
\hline $\begin{array}{l}\text { All intracranial } \\
\text { tumors, cumulative } \\
\text { hours of mobile } \\
\text { phone use }{ }^{b}\end{array}$ & $\begin{array}{l}\text { Hardell et al } 1999 \text { (1), Muscat et al } 2000 \text { (12), Inskip et al } 2001 \\
\text { (13), Hardell et al } 2002 \text { (16), Muscat et al } 2002 \text { (17), Lönn et al } \\
2005 \text { (20), Christensen et al } 2005 \text { (21), Schoemaker et al } 2005 \\
\text { (22), Hardell et al 2005a (23), Hardell et al } 2005 \text { (24) }\end{array}$ & Random effects & 0.98 & $0.73-1.30$ & $\begin{array}{l}\chi^{2}=38.05 \\
\mathrm{P}<0.01\end{array}$ & $\begin{array}{l}\chi^{2}=9.27 \\
P=0.41\end{array}$ \\
\hline $\begin{array}{l}\text { All intracranial } \\
\text { tumors, population } \\
\text { based studies }^{\mathrm{a}}\end{array}$ & $\begin{array}{l}\text { Hardell et al } 1999 \text { (1), Johansen et al } 2001 \text { (14), Auvinen et } \\
\text { al } 2002 \text { (15), Hardell et al } 2002 \text { (16), Lönn et al } 2005 \text { (20), } \\
\text { Christensen et al } 2005 \text { (21), Schoemaker et al } 2005 \text { (22), } \\
\text { Hardell et al 2005a (23), Hardell et al 2005b (24) }\end{array}$ & Random effects & 0.99 & $0.82-1.21$ & $\begin{array}{l}\chi^{2}=24.59 \\
P=0.01\end{array}$ & $\begin{array}{l}\chi^{2}=8.48 \\
P=0.39\end{array}$ \\
\hline $\begin{array}{l}\text { All intracranial } \\
\text { tumors, hospital } \\
\text { based studies a }\end{array}$ & $\begin{array}{l}\text { Muscat et al } 2000 \text { (12), Inskip et al } 2001 \text { (13), Muscat et al } \\
2002 \text { (17) }\end{array}$ & Fixed effects & 0.87 & $0.59-1.30$ & $\begin{array}{l}\chi^{2}=1.78 \\
\mathrm{P}=0.41\end{array}$ & . \\
\hline Gliomas c,d & $\begin{array}{l}\text { Hardell et al } 1999 \text { (1), Muscat et al } 2000 \text { (12), Inskip et al } \\
2001 \text { (13), Johansen et al } 2001 \text { (14), Auvinen et al } 2002 \\
\text { (15), Hardell et al } 2002 \text { (16), Lönn et al } 2005 \text { (20), } \\
\text { Christensen et al } 2005 \text { (21), Hardell et al } 2005 \text { (24) }\end{array}$ & Random effects & 0.96 & $0.78-1.18$ & $\begin{array}{l}\chi^{2}=20.01 \\
P=0.01\end{array}$ & $\begin{array}{l}\chi^{2}=8.64 \\
P=0.37\end{array}$ \\
\hline Meningiomas ${ }^{d}$ & $\begin{array}{l}\text { Hardell et al } 1999 \text { (1), Inskip et al } 2001 \text { (13), Johansen et al } \\
2001 \text { (14), Auvinen et al } 2002 \text { (15), Hardell et al } 2002 \text { (16), Lönn } \\
\text { et al } 2005 \text { (20), Christensen et al } 2005 \text { (21), Hardell et al (23) }\end{array}$ & Fixed effects & 0.87 & $0.72-1.05$ & $\begin{array}{l}\chi^{2}=7.28 \\
P=0.40\end{array}$ & . \\
\hline $\begin{array}{l}\text { Acoustic } \\
\text { neuromas }{ }^{d}\end{array}$ & $\begin{array}{l}\text { Hardell et al } 1999 \text { (1), Inskip et al } 2001 \text { (13), Hardell et al } \\
2002 \text { (16), Muscat et al } 2002 \text { (17), Shoemaker et al } 2005 \\
(22) \text {, Hardell et al } 2005 \text { (23) }\end{array}$ & Fixed effects & 1.07 & $0.89-1.30$ & $\begin{array}{l}\chi^{2}=5.69 \\
P=0.34\end{array}$ & . \\
\hline Analogue phone ${ }^{\mathrm{e}}$ & $\begin{array}{l}\text { Hardell et al } 1999 \text { (1), Auvinen et al } 2002 \text { (15), Hardell et al } \\
2002 \text { (16), Lönn et al } 2005 \text { (20), Schoemaker et al } 2005 \\
\text { (22), Hardell et al } 2005 \text { (23), Hardell et al } 2005 \text { (24) }\end{array}$ & Random effects & 1.17 & $0.91-1.49$ & $\begin{array}{l}\chi^{2}=16.28 \\
P=0.01\end{array}$ & $\begin{array}{l}\chi^{2}=6.11 \\
P=0.41\end{array}$ \\
\hline Digital phone ${ }^{\mathrm{e}}$ & $\begin{array}{l}\text { Hardell et al } 1999 \text { (1), Auvinen et al } 2002 \text { (15), Hardell et al } \\
2002 \text { (16), Lönn et al } 2005(20) \text {, Hardell et al } 2005 \text { (23), } \\
\text { Hardell et al } 2005 \text { (24), Shoemaker et al } 2005 \text { (22) }\end{array}$ & Random effects & 1.04 & $0.80-1.35$ & $\begin{array}{l}\chi^{2}=14.65 \\
\mathrm{P}=0.02\end{array}$ & $\begin{array}{l}\chi^{2}=5.57 \\
\mathrm{P}=0.47\end{array}$ \\
\hline Temporal tumors ${ }^{\dagger}$ & $\begin{array}{l}\text { Hardell et al } 1999 \text { (1), Muscat et al } 2000 \text { (12), Inskip et al } 2001 \\
\text { (13), Johansen et al } 2001 \text { (14), Hardell et al } 2002 \text { (16), Lönn et } \\
\text { al } 2005 \text { (20), Hardell et al } 2005 \text { (23), Hardell et al } 2005 \text { (24) }\end{array}$ & Random effects & 1.02 & $0.68-1.52$ & $\begin{array}{l}\chi^{2}=32.69 \\
\mathrm{P}<0.01\end{array}$ & $\begin{array}{l}\chi^{2}=6.81 \\
P=0.45\end{array}$ \\
\hline Occipital tumors ${ }^{g}$ & $\begin{array}{l}\text { Muscat et al } 2000 \text { (12), Inskip et al } 2001 \text { (13), Johansen et } \\
\text { al } 2001 \text { (14), Hardell et al } 2002 \text { (16), Lönn et al } 2005 \text { (20) }\end{array}$ & Fixed effects & 0.82 & $0.54-1.25$ & $\begin{array}{l}\chi^{2}=3.29 \\
P=0.52\end{array}$ & . \\
\hline $\begin{array}{l}\text { Contralateral } \\
\text { tumors }{ }^{h, i}\end{array}$ & $\begin{array}{l}\text { Hardell et al } 2002 \text { (16), Lönn et al } 2005 \text { (20), Schoemaker et al } \\
2005 \text { (22), Hardell et al } 2005 \text { (23), Hardell et al } 2005 \text { (24) }\end{array}$ & Random effects & 1.02 & $0.78-1.35$ & $\begin{array}{l}\chi^{2}=11.56 \\
P=0.02\end{array}$ & $\begin{array}{l}\chi^{2}=4.30 \\
P=0.37\end{array}$ \\
\hline $\begin{array}{l}\text { Ipsilateral } \\
\text { tumors }{ }^{h, j}\end{array}$ & $\begin{array}{l}\text { Hardell et al } 1999 \text { (1), Inskip et al } 2001 \text { (13), Hardell et al } 2002 \\
\text { (16), Muscat et al } 2002 \text { (17), Lönn et al } 2005 \text { (20), Schoemaker } \\
\text { et al } 2005 \text { (22), Hardell et al } 2005 \text { (23), Hardell et al } 2005 \text { (24) }\end{array}$ & Random effects & 1.36 & $0.99-1.87$ & $\begin{array}{l}\chi^{2}=24.51 \\
P=0.01\end{array}$ & $\begin{array}{l}\chi^{2}=10.70 \\
P=0.15\end{array}$ \\
\hline Ipsilateral gliomas ${ }^{\mathrm{i}}$ & $\begin{array}{l}\text { Hardell et al } 1999 \text { (1), Inskip et al } 2001 \text { (13), Lönn et al } \\
2005 \text { (20), Hardell et al } 2005 \text { (24) }\end{array}$ & Random effects & 1.33 & $0.78-2.28$ & $\begin{array}{l}\chi^{2}=10.34 \\
P=0.02\end{array}$ & $\begin{array}{l}\chi^{2}=2.67 \\
P=0.45\end{array}$ \\
\hline $\begin{array}{l}\text { Ipsilateral } \\
\text { meningiomas i }\end{array}$ & $\begin{array}{l}\text { Hardell et al } 1999 \text { (1), Inskip et al } 2001 \text { (13), Lönn et al } \\
2005 \text { (20), Hardell et al } 2005 \text { (24) }\end{array}$ & Fixed effects & 1.16 & $0.82-1.63$ & $\begin{array}{l}\chi^{2}=1.96 \\
\mathrm{P}=0.58\end{array}$ & . \\
\hline $\begin{array}{l}\text { Ipsilateral acoustic } \\
\text { neuromas i }\end{array}$ & $\begin{array}{l}\text { Inskip et al } 2001 \text { (13), Muscat et al } 2002 \text { (17), Schoemaker } \\
\text { et al } 2005 \text { (22), Hardell et al } 2005 \text { (23) }\end{array}$ & Random effects & 1.05 & $0.41-2.67$ & $\begin{array}{l}\chi^{2}=10.91 \\
P=0.01\end{array}$ & $\begin{array}{l}\chi^{2}=4.62 \\
P=0.20\end{array}$ \\
\hline
\end{tabular}

a The longest duration of exposure was $>5$ years in all other reports, except in that of Muscat et al (12), in which $>4$ years was used, that of Johansen et al

(14) with a mean follow-up time of 3.1 years, that of Auvinen et al (15), in which $>2$ years was used, and that of Muscat et al (17), which used 3-6 years.

${ }^{b}$ The exposure was defined as $\geq 424$ hours in all other reports, except in that of Hardell et al (16), in which $>55$ hours was used, in that of Muscat et al (17), in which $>60$ hours was used, and in those of Hardell et al $(23,24)$, in which $>64$ hours was used.

' The glioma group consisted of astrocytic, oligodendroglial, and ependymal tumors and mixed gliomas.

d The exposure was defined as $>5$ years in all other reports, except in those of Hardell et al $(1,16)$, in which $>1$ years was used, in that of Muscat et al (12), in which $>4$ years was used, in that of Johansen et al (14), which reported "ever use", in that of Auvinen et al (15), in which $>2$ years was used, and in that of Muscat et al (17) in which 3-6 years was used.

${ }^{\mathrm{e}}$ The exposure was defined as $>5$ years in all other reports except in that of Auvinen et al (15), in which $>2$ years was used.

'The exposure was defined as $>5$ years in all other reports, except in that of Hardell et al (1), in which $>1$ years was used, in that of Muscat et al (12), which reported "ever use", in that of Inskip et al (13), which reported "used more than five times", and in that of Johansen et al (14), in which the exposure duration was undefined.

9 The exposure was defined as "ever use" in that of Muscat et al 12, "used more than five times" in that of Inskip et al (13), >1 years in that of Hardell et al (16), and $>5$ years in that of Lönn et al (20), whereas in that of Johansen et al (14) the exposure duration was undefined.

${ }^{n}$ Contralateral $=$ tumor located on the side opposite of that generally used for the mobile phone, ipsilateral = tumor located on the same side generally used for the mobile phone.

' The exposure was defined as $>1$ years in all other reports except in those of Lönn et al (20) and Hardell et al (24), in which $>5$ years was used.

i The exposure was defined as $>1$ years in all other reports, except in that of Inskip et al (13) in which >0.5 years was used and in those of Lönn et al (20) and Hardell et al (24) in which $>5$ years was used. 


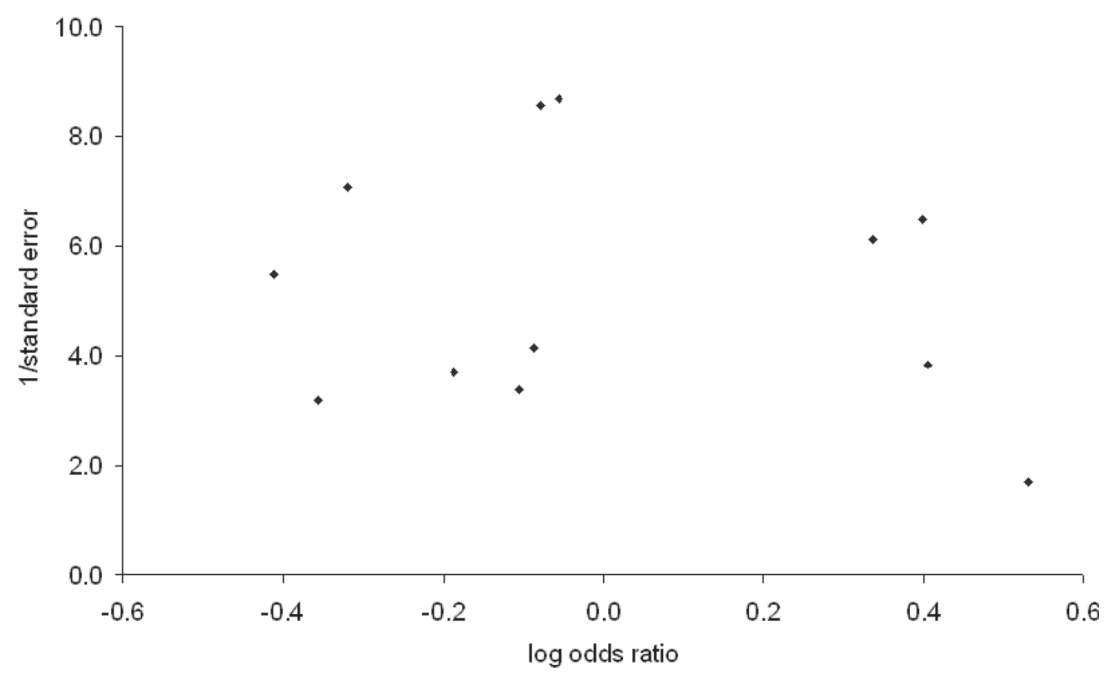

Figure 3. Funnel plot of the studies included in the meta-analysis, showing no evidence of publication bias concerning intracranial tumors and mobile phone use. acoustic neuroma) or anatomic location (temporal or occipital lobe) of intracranial tumors. The regression analysis showed no clear association between the duration of mobile phone use and the risk of intracranial tumors.

A somewhat increased odds ratio for ipsilateral tumors was found, but the finding was nonsignificant. On the contrary, the pooled odds ratio for contralateral tumors was very close to unity. It is evident that the reported use of a mobile phone is subject to uncertainty due to both random error and information bias (recall bias). Several studies have shown substantial random error already for the short-term recall of mobile phone use (27-29). No studies have been reported with respect to comparing the accuracy of reported mobile phone use between cases and controls to evaluate possible information bias. However, the fact that some studies have shown decreased risks on the contralateral side suggests information bias $(16,20)$.

Our analysis was based on users with the longest possible duration of mobile phones. In most studies, these were people with at least 5 years of mobile phone use. This approach was chosen a priori, as mobile phones have been introduced relatively recently and therefore a sufficient duration of exposure and latency to allow detection of possible effect was considered a key limitation of the published studies. We felt that the gains of having a well-defined exposed group with the highest achievable duration of exposure outweighed the disadvantage of excluding $50 \%$ of the persons in the intermediate exposure category. Five years is still, however, a relatively short time for the induction of intracranial tumors, even if the postulated mechanism, if any, has been thought to be based on promotion rather than on initiation because radiofrequency fields do not have the energy to break the chemical bonds (cause ionization) required for inducing mutations. Hence a limitation of the studies conducted so far is the relatively small number of persons with long-term (eg, more than 10 years) mobile phone use.

Meta-analyses of nonrandomized studies are more prone to bias than those combining experimental studies. One source of uncertainty is different adjustment for confounding between studies. All of the studies in the current meta-analysis used adjustment for age and gender. Other established risk factors for intracranial tumors include hereditary factors and high doses of ionizing radiation. These are, however, relatively rare. In several studies, the influence of these factors was assessed by conducting separate analyses excluding persons with such exposures. As none of the studies reported a substantial effect in such analyses, confounding by these factors appears unlikely. We did not use quality assessment and scoring because the methodology in all of the studies was similar.

We found statistically significant heterogeneity between the results from different studies in the main analysis of all intracranial tumors and additionally in 11 of 16 subgroup analyses. This finding could be due to differences between the studies in procedures or definitions related to end points or exposure assessment. An alternative explanation for inconsistent results is the variability of the true effect between study populations [eg, due to exposure patterns such as the intensity of mobile phone use, field strength (specific absorption rate) or other features].

Furthermore, pooling studies requires that they have been conducted in a comparable fashion, and the published reports contain the essential information to be extracted. We found some inconsistencies in the exposure classification between the studies. Most importantly, the cut-point for the longest exposure duration varied between studies. Furthermore, five studies did not report analogue and digital phones separately, four did not specify the laterality of mobile phone use, and three studies of astrocytomas did not specify tumor lobe. 
Due to the incomplete reporting of data in published studies, we were not able to evaluate several factors simultaneously (eg, ipsilateral acoustic neuromas) in relation to use of analogue phones. We chose to exclude a cohort study with brain tumor mortality as the end point because, in such analyses, determinants of survival (case fatality) may also affect the results if correlated with the exposure of interest (7). In this case, the study was so small (2 exposed cases) that its inclusion would not have affected our results.

The number of intracranial tumors among long-term mobile phone users in the current meta-analysis was still only approximately 750 . However, results from this meta-analysis indicate that the use of mobile phones for up to 5 years does not increase intracranial tumor risk.

\section{References}

1. Hardell L, Näsman Å, Påhlson A, Hallquist A, Hansson Mild $\mathrm{K}$. Use of cellular telephones and the risk for brain tumours: a case-control study. Int J Oncol. 1999;15:113-6.

2. Blettner M, Berg G. Are mobile phones harmful? Acta Oncol. 2000;39:927-30.

3. Frumkin H, Jakobson A, Gansler T, Thun MJ. Cellular phones and risk of brain tumors. CA Cancer J Clin. 2001;51:137-41.

4. Independent Expert Group on Mobile Phones (IEGMP). Mobile phones and health. Chilton (UK): National Radiological Protection Board; 2000.

5. Boice JD, McLaughlin JK. Epidemiologic studies of cellular telephones and cancer risk-a review (SSI Report 2002-16). Stockholm: Swedish Radiation Protection Authority; 2002.

6. Ahlbom A, Green A, Kheifets L, Savitz D, Swerdlow A, International Committee for Non-Ionizing Radiation Protection (ICNIRP) Standing Committee on Epidemiology. Epidemiology of health effects of radiofrequency exposure. Environ Health Perspect. 2004;112:1741-54.

7. Dreyer NA, Loughlin JE, Rothman KJ. Cause-specific mortality in cellular telephone users. JAMA. 1999;282:1814-6.

8. Warren HG, Prevatt AA, Daly KA, Antonelli PJ. Cellular telephone use and risk of intratemporal facial nerve tumor. Laryngoscope. 2003;113:663-7.

9. Hardell L, Hansson Mild K, Påhlson A, Hallquist A. Ionizing radiation, cellular telephones and the risk for brain tumours. Eur J Cancer Prev. 2001;10:523-9.

10. Hardell L, Mild KH, Carlberg M. Case-control study on the use of cellular and cordless phones and the risk of malignant brain tumors. Int J Radiat Biol. 2002;78:931-6.

11. Hardell L, Mild KH, Carlberg M. Further aspects on cellular and cordless telephones and brain tumours. Int $\mathrm{J}$ Oncol. 2003;22:399-407.

12. Muscat JE, Malkin MG, Thompson S, Shore RE, Stellman SD, McRee D, et al. Handheld cellular telephone use and risk of brain cancer. JAMA. 2000;284:3001-7

13. Inskip PD, Tarone RE, Hatch EE, Wilcosky TC, Shapiro WR, Selker RG, et al. Cellular-telephone use and brain tumors. N
Engl J Med. 2001;344:79-86.

14. Johansen K, Boice JD, McLaughlin J, Olsen J. Cellular telephones and cancer - a nationwide cohort study in Denmark. J Natl Cancer Inst. 2001;93:203-7.

15. Auvinen A, Hietanen M, Luukkonen R, Koskela R-S. Brain tumors and salivary gland cancers among cellular telephone users. Epidemiology. 2002;13:356-9.

16. Hardell L, Hallquist A, Hansson Mild K, Carlberg M, Påhlson A, Lilja A. Cellular and cordless telephones and the risk for brain tumours. Eur J Cancer Prev. 2002;11:377-86.

17. Muscat JE, Malkin MG, Shore RE, Thompson S, Neugut AI, Stellman SD, et al. Handheld cellular telephones and risk of acoustic neuroma. Neurology. 2002;58:1304-6.

18. Christensen HC, Schüz J, Kosteljanetz M, Poulsen HS, Thomsen J, Johansen C. Cellular telephone use and risk of acoustic neuroma. Am J Epidemiol. 2004;159:277-83.

19. Lönn S, Ahlbom A, Hall P, Feychting M. Mobile phone use and the risk of acoustic neuroma. Epidemiology. 2004;15:653-9.

20. Lönn S, Ahlbom A, Hall P, Feychting M, Swedish Interphone Study Group. Long-term mobile phone use and brain tumor risk. Am J Epidemiol. 2005;161:526-35.

21. Christensen HC, Schutz J, Kosteljanetz M, Skovgaard Poulsen H, Boice JD, McLaughlin JK, et al. Cellular telephones and risk for brain tumors: a population based, incident case-control study. Neurology. 2005;64:1189-95.

22. Schoemaker MJ, Swerdlow AJ, Ahlbom A, Auvinen A, Blaasaas K, Cardis E, et al. Mobile phone use and risk of acoustic neuroma: results of the Interphone case-control study in five North European countries. Br J Cancer. 2005;93:8428.

23. Hardell L, Carlberg M, Hansson Mild K. Case-control study on cellular and cordless telephones and the risk for acoustic neuroma or meningioma in patients diagnosed 2000-2003. Neuroepidemiology. 2005;25:120-8.

24. Hardell L, Carlberg M, Mild KH. Case-control study of the association between the use of cellular and cordless telephones and malignant brain tumors diagnosed during 2000 2003. Environ Res. In press

25. Sutton AJ, Abrams KR, Jones DR, Sheldon TA, Song F. Methods for meta-analysis in medical research. Chichester (UK): John Wiley \& Sons Ltd; 2000.

26. Advisory Group on Non-Ionizing Radiation (AGNIR). Health effects from radiofrequency electromagnetic fields: report of an independent Advisory Group of Non-Ionising Radiation. Doc NRPB. 2003;14:1-177

27. Parslow RC, Hepworth SJ, McKinney PA. Recall of past use of mobile phone handsets. Radiat Prot Dosimetry. 2003;106:233-40.

28. Samkange-Zeeb F, Berg G, Blettner M. Validation of selfreported cellular phone use. J Expo Anal Environ Epidemiol. 2004; 14:245-8.

29. Berg G, Schutz J, Zamkange-Zeeb F, Blettner M. Assessment of radiofrequency exposure from cellular telephone daily use in an epidemiological study: German validation study of the international case-control study of cancers of the brain-INTERPHONE study. J Expo Anal Environ Epidemiol. 2005;15:217-24.

Received for publication: 29 August 2005 